\title{
Robotic Space and Earth Science 2020
}

\author{
Charles Elachi \\ California Institute of Technology Jet Propulsion Laboratory, Pasadena, CA USA
}

Abstract-Plenary Talk 